activity of the intellect is 'cinematographical', always reflecting its ancient office as the servant of practice in the struggle for existence. Even in science intellection is not freed from its subservience to practical purposes, and the result is that the world is seen as made up of separate items loosely inter-related in a mechanical fashion. It substitutes succession for the continuity of real duration, taking, as it were, static snapshots of a continuous movement. Metaphysical intuition, however, which is instinct become selfconscious, affords knowledge of real time as distinct from discrete points in motion and separate moments in time. The immediacy of intuition is not the clearcut focus of present consciousness; but is coextensive with the wide range of possible experience and includes the whole past which "swells with the duration it accumulates" as it "gnaws into the future". Intuition is thus a sort of intellectual sympathy whereby the mind is transported into the objective flux at the heart of things.

Bergson employed the term 'space' to denote the form which characterizes the dead abstractions of the intellect as opposed to the pulsations of real duration. Spatiality belongs to all that is held to consist of mutually exclusive items externally related to one another. Hence, all spatiality necessarily involved in the linguistic expression of the living disclosures of intuition must be discounted, for such expressions are only aids to, and not substitutes for, the direct acquaintance of intuition itself. But Bergson did not hold that the intellect is wholly arbitrary in its excogitation of abstractions, for reality itself, being amenable to scientific classification, must contain a tendency towards the logical distinctness of spatiality. It is not saturated with duration so as to constitute an absolute creative synthesis. Like a fountain, reality has upward and downward trends, and both 'matter' and 'memory' are derivative abstractions.

This general conception had a liberating effect on the thought of the time. It emancipated the intellect from the narrow limits to which it had been restricted by the mechanically conceived natural science of the nineteenth century. It made plain the inadequacy of scientific mechanism as a metaphysic. But in our view it was unfortunate that Bergson himself continued to have a restricted view of intellection or reason, and represented it as a spatializing faculty. If this were really the case, one would think that there would be no sciences, but those of a geometrical character. In other words, what is required for the avoidance of narrow abstraction in philosophy is not a repudiation of reason, or its supplementation by another faculty, but a broadening of the traditionally 'rational' attitude to life so that it is contemplated in all its wealth of variety.

The restriction in question has, in fact, had lamentable consequences of which Bergson himself did not approve. Only those with a superficial understanding of his work could say that his philosophy sanctioned crude anti-rationalism. He never despised the intellectual disciplines or regarded intuition as a kind of short-cut to reality. This is clearly shown by his own methods of investigation.
Thus, the "Essai" issued from a careful examination of the findings of experimental psychology. When preparing "Matter and Memory" he devoted five years to the study of the medical literature on aphasia. He believed that the discovery of the cerebral localization of the speech centres shed light on the ancient problem of the mind-body relation. Surely empirical science was never brought into closer relation with metaphysics! Again, he did not put forward his theory of creative evolution until he had acquired a thorough knowledge of the available biological evidence.

Bergson possessed great personal charm. Lucidity characterized both his writings and lectures. There was something of the poet in him and he was a master of the French language. During the years immediately preceding the War of 1914-18 his popularity was at its height, and fashionable audiences thronged his lecture-room. He was besieged with invitations to lecture in different parts of the world. As we would expect, the influence of his thought was widespread. Georges Sorel, the syndicalist, Marcel Proust, the man of letters, and Prof. E. Le Roy, the mathematician and liberal Catholic, were all, in spite of the great differences between them, profoundly influenced by Bergson's philosophy. There was something romantic about William James' professed conversion to Bergsonianism.

I met Bergson at his country residence near Tours in June 1939. He was then suffering from paralysis and unable to walk, but his mental faculties were alive. Undaunted by the rising tide of nationalism in Europe, he was still working for more effective international co-operation in intellectual matters. There was the threat of war and a sense of impending disaster in the air. But the aged philosopher was not despairing. He declared that it is generally through the travail of bitter experience that man rises to make his noblest achievements. ALEC BURKILL.

\section{Prof. Robert Howden}

THE death of Robert Howden, emeritus professor of anatomy in the University of Durham, on December 7 , removes one of the great anatomists of the Edinburgh School and a figure noteworthy in the history of the University of Durham College of Medicine, Neweastle-upon-Tyne.

$\mathrm{He}$ was born at Braco in Perthshire in 1856 and after qualifying at Edinburgh in 1884 he became demonstrator in anatomy under Sir William Turner. At this time, the Edinburgh School was the source of the majority of candidates for the British chairs of anatomy, and in due course Howden crossed the border to take up an appointment in Newcastle. He was appointed lecturer in the College of Medicine in 1887 and four years later became the first professor of anatomy at Newcastle. He held this position until his retirement in 1927. His appointment coincided with the time when the rapid increase in the size of the School necessitated its removal from the small and inconvenient buildings in Orchard Street to the much more commodious premises in Northumberland 
Road, which were to be the home of the College for fifty years and were only vacated in 1938 .

Coming to the School when it was really taking on functions of vastly increased importance as a college in the modern use of the term, it is obvious that Howden must have found plenty of work to occupy his time and energy. He commenced with the development of his own department, and enriched it with many beautiful mounted specimens of his own dissection which replaced the old dried and varnished specimens previously in use. He also provided for the department a series of wall diagrams, many of them his own handiwork, which were a great adjunct to his teaching and some of which are in use to this day. Anyone familiar with the labour which this type of work entails will appreciate how much time he must have devoted to his department in these earlier days.

Howden's undoubted teaching ability soon expressed itself and contributed largely to the growth and success of the School at a crucial stage of its development. Those who knew him at this time recall the vigour and energy which he put into his work not only in the dissecting room, but also in his lectures and demonstrations. They recall, too, his great artistic ability on the blackboard and the care with which his lectures were illustrated by diagrams and beautifully dissected specimens.

During those early years in Newcastle, Howden was the only full-time member of the staff, and being thus always available in the building, management and administrative duties were loaded upon him, so that in due course he became secretary, dean of the Faculty of Medicine and registrar in addition to maintaining his professorial duties. It has been said by Grey Turner in his "History" of the College that Howden gradually became something of a dictator, but that he was a wise and considerate dictator. Anyone who was not associated with the College during this time of Howden's greatest activity may fail to appreciate the important part he played in the life of the College, or the way in which both staff and students came to rely upon his wisdom, his guidance and his sympathy. Through the generations of students who came under his care he exercised a profound influence on the medical profession in the north of England. $\mathrm{He}$ represented the University of Durham on the General Medical Council during 1918-28 and he was examiner in anatomy for the Universities of Edinburgh, Oxford, Cambridge, Liverpool and Birmingham and for the Conjoint Board of the Royal Colleges of Physicians and Surgeons.

Though so much occupied with administrative and teaching duties, Howden still found time to advance the study of his subject. Between the years 1886 and 1897 he made several communications to the Anatomical Society of Great Britain and Ireland, and in later years he continued his interest in the Society and was its president in 1914-16. He also edited nine successive editions of "Gray's Anatomy", and through this medium he spread his influence far beyond the confines of the School for which he worked. In his editorial work he maintained that meticulous attention to detail both in the text and in the illustrations which did so much to enhance the prestige of this text-book. He was also responsible for the section of "Cunningham's Anatomy" dealing with the special senses.

Howden was a kindly and generous man, polite and courteous; he was always helpful to his juniors and was never too busy to listen to their problems and to help by advice and encouragement, though he did not suffer fools gladly or tolerate slackness. $\mathrm{He}$ was a charming companion and found many friends in the pursuit of his favourite recreations, which included golf, fishing and curling. $\mathrm{H}_{\theta}$ is survived by his widow and leaves three sons and two daughters.

R. B. G.

News has just reached us of the death recently in Prague of Dr. Duchoslav Panýrek, a well-known Czech medical scientist. He was the author of several widely read books of popular science and translated others from French, Russian and other languages into Czech. Dr. Panýrek took a prominent part in Slavonic medical and scientific congresses and had been awarded the Jugoslavian Order of St. Sava. He was seventy-three years of age.

The vice-president of the Czech Astronomical Society, Dr. Jaroslar Stych, also died in Prague early in January.

WE regret to announce the following deaths :

Dr. Alexander Bowman, formerly scientific superintendent, Scottish Fishery Board, on January 14, aged sixty-four.

Prof. B. P. Haigh, M.B.E., profe ssor of applied mechanics in the Royal Naval College, Greenwich, on January 18, aged fifty-six.

Prof. H. S. Hele-Shaw, F.R.S., emeritus professor of engineering in the University of Liverpool, on January 30, aged eighty-six.

Sir William Horrocks, K.C.M.G., C.B., who was a member of the Mediterranean Fever Commission of the Royal Society (1904-5), and later director of hygiene at the War Office, aged eighty-one.

Mr. C. Thurstan Holland, a pioneer in the application of X-rays to medical and surgical work, on January 16, aged seventy-seven.

Sir John McFadyean, formerly principal of the Royal Veterinary College, on February 1, aged eighty-seven.

Mr. J. H. Silley, O.B.E., the well-known marine engineer, on January 24, aged sixty-eight.

Mr. A. J. Smith, chief laboratory assistant to the Marine Biological Association at Plymouth, on January 29, aged sixty-nine.

Sir Pendrill Varrier-Jones, founder and director of the Papworth Village Settlement, on January 30, aged fifty-seven.

Dr. G. E. Vincent, president of the University of Minnesota during 1911-17, and of the Rockefeller Foundation in New York during 1917-29, on February 1, aged seventy-six. 